\title{
Halorubrum arcis sp. nov., an extremely halophilic archaeon isolated from a saline lake on the Qinghai-Tibet Plateau, China
}

Correspondence
Min Wu
wumin@zju.edu.cn

\author{
Xue-Wei Xu, ${ }^{1}$ Yue-Hong Wu, ${ }^{1}$ Hui-bin Zhang $^{2}$ and Min Wu ${ }^{1}$ \\ ${ }^{1}$ College of Life Sciences, Zhejiang University, Hangzhou 310058, People's Republic of China \\ ${ }^{2}$ Altun Mountain National Nature Reserve Administrative, Kuerle 841000, People's Republic of \\ China
}

\begin{abstract}
A Gram-negative, aerobic, neutrophilic and extremely halophilic archaeon (strain $\mathrm{AJ} 201^{\top}$ ), isolated from Ayakekum salt lake on the Qinghai-Tibet Plateau, was investigated by a polyphasic approach. The DNA G +C content of strain AJ $201^{\top}$ was $65.7 \mathrm{~mol} \%$. The major polar lipid profile and phylogenetic analysis based on 16S rRNA gene sequences supported the allocation of the strain to the genus Halorubrum. The results of DNA-DNA hybridizations and physiological and biochemical tests allowed genotypic and phenotypic differentiation of strain $\mathrm{AJ} 201^{\top}$ from closely related species. Therefore, strain $\mathrm{AJ} 201^{\top}$ represents a novel species of the genus Halorubrum, for which the name Halorubrum arcis sp. nov. is proposed. The type strain is strain $\mathrm{AJ}_{201}{ }^{\top}(=\mathrm{CGMCC}$ $1.5343^{\top}=$ JCM $13916^{\top}$ ).
\end{abstract}

Members of the genus Halorubrum (McGenity \& Grant, 1995; Kamekura \& Dyall-Smith, 1995) are widely distributed in hypersaline habitats (Grant \& Larsen, 2001). At the time of writing, there are 16 species with validly published names in the genus Halorubrum, including three alkaliphilic species, Halorubrum vacuolatum (Mwatha \& Grant, 1993; Kamekura et al., 1997), Hrr. tibetense (Fan et al., 2004) and Hrr. alkaliphilum (Feng et al., 2005), and 13 neutrophilic species, Halorubrum saccharovorum (the type species; Tomlinson \& Hochstein, 1976), Hrr. sodomense (Oren, 1983), Hrr. lacusprofundi (Franzmann et al., 1988), Hrr. coriense (Nuttall \& Dyall-Smith, 1993), Hrr. trapanicum (McGenity \& Grant, 1995; Trüper, 2003), Hrr. distributum (Zvyagintseva \& Tarasov, 1987; Oren \& Ventosa, 1996), Hrr. tebenquichense (Lizama et al., 2002), Hrr. terrestre (Ventosa et al., 2004), Hrr. xinjiangense (Feng et al., 2004), Hrr. ezzemoulense (Kharroub et al., 2006), Hrr. orientale (Castillo et al., 2006), Hrr. lipolyticum (Cui et al., 2006) and Hrr. aidingense (Cui et al., 2006). Here, we report the taxonomic characterization of a neutrophilic strain belonging to the genus Halorubrum.

Strain AJ201 ${ }^{\mathrm{T}}$ was isolated from mud of Ayakekum salt lake $\left(37^{\circ} 37^{\prime} \mathrm{N} 89^{\circ} 29^{\prime} \mathrm{E}\right.$; $3884 \mathrm{~m}$ altitude) located in the Altun Mountain, in the northern part of the Qinghai-Tibet Plateau. The lake environment was described previously in

The GenBank/EMBL/DDBJ accession number for the 16S rRNA gene sequence of strain $\mathrm{AJ} 201^{\top}$ is DQ355793.

Results of one-dimensional TLC of polar lipids of Hrr. saccharovorum CGMCC $1.2147^{\top}$ and strain AJ201 ${ }^{\top}$ are available as supplementary material in IJSEM Online. detail (Xu et al., 2005a). The sample was incubated with S-G medium (Sehgal \& Gibbons, 1960) for approximately 1 week and the liquid was plated by using a tenfold dilution series method. After 1-2 weeks of incubation at $37^{\circ} \mathrm{C}$, a representative red colony was picked and maintained on S-G medium. The strain was purified by repeated restreaking; purity was confirmed by the uniformity of cell morphology. The optimal conditions for growth were determined in S-G medium modified with $0.85-5.1 \mathrm{M} \mathrm{NaCl}$ or $0-1.0 \mathrm{M} \mathrm{Mg}^{2+}$.

Phenotypic tests and lipid analysis were performed according to $\mathrm{Xu}$ et al. (2005b) as mentioned previously in the minimal standards for the description of new taxa in the order Halobacteriales (Oren et al., 1997). Detailed results of cell morphology, physiological tests and antibiotic sensitivity are given in the species description. The major polar lipids of strain $\mathrm{AJ} 201^{\mathrm{T}}$ were determined to be $\mathrm{C}_{20} \mathrm{C}_{20}$ derivatives of phosphatidylglycerol, phosphatidylglycerol phosphate methyl ester, phosphatidylglycerol sulfate and sulfated mannosyl-glucosyl-glycerol diether (Supplementary Fig. S1 in IJSEM Online).

The 16S rRNA gene was amplified and analysed as described previously (Xu et al., 2005b). The almost-complete 16S rRNA gene sequence of strain AJ201 ${ }^{\mathrm{T}}$ (1470 nt; nucleotide positions 6-1540 in the Escherichia coli numbering) showed 92.9-97.5\% similarity to those of the type strains of Halorubrum species. A phylogenetic tree was constructed by the neighbour-joining method with the MEGA3 program package (Kumar et al., 2004), after multiple alignment of the data by CLUSTAL_X (Thompson et al., 1997). The neighbour-joining tree (Fig. 1) showed that strain $\mathrm{AJ} 201^{\mathrm{T}}$ 


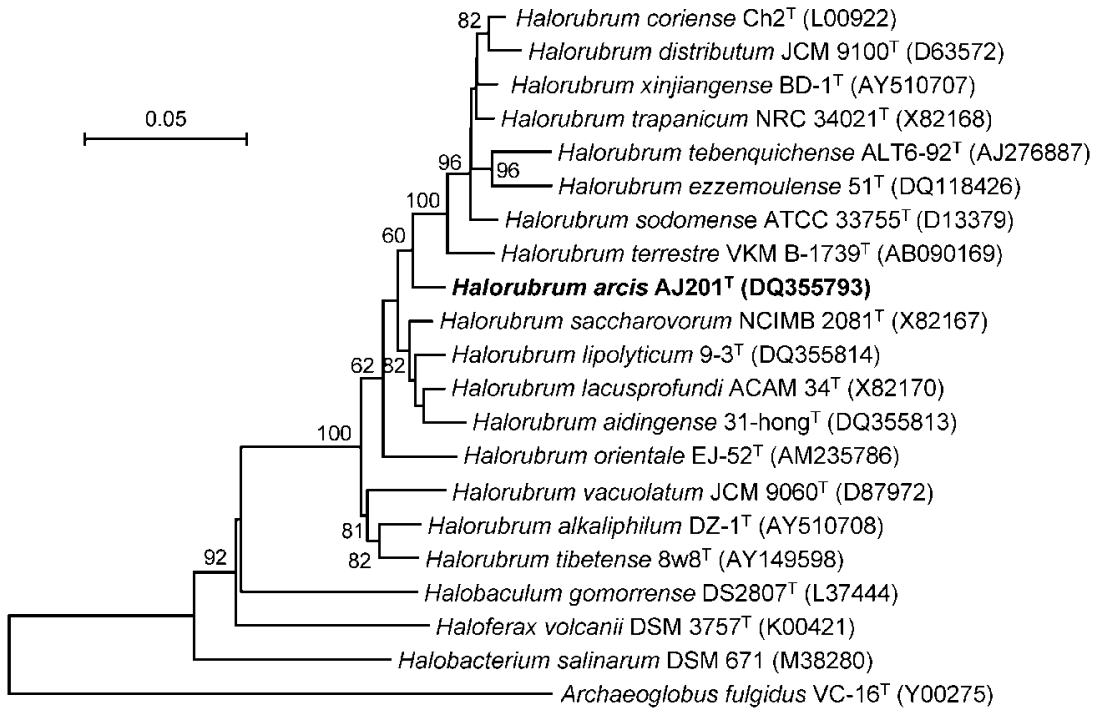

Fig. 1. Neighbour-joining tree based on $16 \mathrm{~S}$ rRNA gene sequences, showing the phylogenetic relationships of strain $\mathrm{AJ} 201^{\top}$ and related taxa. Bootstrap values are based on 1000 replicates; only values $\geqslant 60 \%$ are shown. Bar, 0.05 substitutions per nucleotide position. clustered with the neutrophilic Halorubrum species. The DNA G + C content of strain AJ201 ${ }^{\mathrm{T}}$ determined by thermal denaturation $\left(T_{\mathrm{m}}\right)$ (Marmur \& Doty, 1962) was 65.7 \pm $0.5 \mathrm{~mol} \%$. DNA-DNA hybridizations were carried out in $2 \times \mathrm{SSC}$ at $80{ }^{\circ} \mathrm{C}$ by following the procedure of De Ley et al.
(1970), as modified by Huß et al. (1983), using a Beckman Coulter DU800 spectrophotometer. DNA-DNA hybridization experiments (Table 1) showed hybridization values between strain $\mathrm{AJ} 201^{\mathrm{T}}$ and closely related species of the genus Halorubrum ranging between 14 and $46 \%$, thus

Table 1. Differential phenotypic characteristics of strain $A J 201^{\top}$ and type strains of closely related Halorubrum species

Strain: 1, AJ201 ${ }^{\mathrm{T}}$; 2, Hrr. saccharovorum CGMCC $1.2147^{\mathrm{T}} ; 3$, Hrr. lacusprofundi CGMCC $1.3490^{\mathrm{T}} ; 4$, Hrr. sodomense CGMCC $1.2206^{\mathrm{T}}$; 5, Hrr. terrestre JCM $10247^{\mathrm{T}}$; 6, Hrr. coriense CGMCC $1.3492^{\mathrm{T}}$; 7 , Hrr. distributum CGMCC $1.3491^{\mathrm{T}}$; 8, Hrr. tebenquichense JCM $12290^{\mathrm{T}}$; 9, Hrr. trapanicum JCM $10477^{\mathrm{T}}$. + , Positive; - , negative; \pm , slightly positive; ND, not determined. Data were from our own comparative tests. All strains were positive for catalase and oxidase and produced acid from glycerol. They all showed negative reactions for gelatinase and indole formation.

\begin{tabular}{|c|c|c|c|c|c|c|c|c|c|}
\hline Characteristic & 1 & 2 & 3 & 4 & 5 & 6 & 7 & 8 & 9 \\
\hline $\mathrm{H}_{2} \mathrm{~S}$ formation from thiosulfate & + & + & - & + & - & + & + & + & + \\
\hline \multicolumn{10}{|l|}{ Hydrolysis of: } \\
\hline Starch & + & - & - & + & - & - & - & - & - \\
\hline Tween 80 & - & - & - & ND & - & - & - & - & ND \\
\hline \multicolumn{10}{|l|}{ Utilization of: } \\
\hline L-Aspartate & - & - & - & - & - & + & - & + & - \\
\hline L-Arginine & - & - & - & - & - & - & - & \pm & - \\
\hline \multicolumn{10}{|l|}{ Acid production from: } \\
\hline Fructose & - & \pm & - & \pm & - & - & - & - & - \\
\hline Glucose & + & + & - & + & - & + & + & - & + \\
\hline Mannose & - & \pm & - & - & - & - & - & - & - \\
\hline Starch & \pm & + & - & \pm & - & - & - & - & - \\
\hline Arabinose & - & + & - & - & - & - & - & - & - \\
\hline Maltose & + & + & - & + & - & - & + & - & + \\
\hline Galactose & - & \pm & \pm & + & - & + & \pm & + & + \\
\hline D-Ribose & - & + & - & - & - & - & - & - & - \\
\hline Sucrose & - & \pm & - & + & - & - & - & - & \pm \\
\hline D-Xylose & - & + & - & \pm & - & - & - & - & - \\
\hline DNA-DNA hybridization with strain $\mathrm{AJ} 201^{\mathrm{T}}(\%)$ & 100 & 17 & 21 & 44 & 44 & 46 & 23 & 27 & 40 \\
\hline
\end{tabular}


indicating that this strain represents a novel species of the genus Halorubrum.

The phenotypic and polar lipid characteristics suggest that strain AJ201 ${ }^{\mathrm{T}}$ is a member of the genus Halorubrum. Differential phenotypic properties shown in Table 1 as well as $16 \mathrm{~S}$ rRNA gene sequence analysis and DNA-DNA hybridization data justify the creation of a novel species, for which we propose the name Halorubrum arcis sp. nov.

\section{Description of Halorubrum arcis sp. nov.}

Halorubrum arcis (ar' cis. L. gen. $\mathrm{n}$. arcis of a height, summit or peak, referring to the isolation of the type strain from a saline lake on the Qinghai-Tibet Plateau).

Gram-negative and motile. Young cultures show rod-like cells $(0.5-1 \times 2-4 \mu \mathrm{m})$. Colonies on complex agar medium are $1-2 \mathrm{~mm}$ in diameter, smooth, circular, elevated and red. Halophilic. Cells lyse immediately in distilled water. $\mathrm{NaCl}$ concentration required for growth is $2.2-5.2 \mathrm{M}$, with an optimum at 3.4-3.9 M. Magnesium is not required for growth, and the optimum $\mathrm{Mg}^{2+}$ concentration is 20$200 \mathrm{mM}$. The $\mathrm{pH}$ and temperature for growth are $\mathrm{pH} 6.0$ 8.5 (optimum $\mathrm{pH} 7.5$ ) and $25-55^{\circ} \mathrm{C}$ (optimum $42^{\circ} \mathrm{C}$ ). Chemo-organotrophic and aerobic. Oxidase- and catalasepositive. Anaerobic growth does not occur with arginine or DMSO. Nitrate is reduced to nitrite. $\mathrm{H}_{2} \mathrm{~S}$ is produced from thiosulfate. Starch is hydrolysed. Tween 80 and casein are not hydrolysed. Gelatin is not liquefied. Casamino acids are required for growth. The following substrates are utilized for growth: glucose, maltose, glycerol and starch. No growth is observed on arabinose, fructose, galactose, lactose, mannitol, mannose, rhamnose, ribose, sorbitol, sucrose, xylose, alanine, arginine, aspartate, glycine, glutamate, lysine, ornithine, acetate, citrate, fumarate, lactate, malate, propionate, pyruvate or succinate. Acid is produced from glucose, maltose and glycerol. Sensitive to novobiocin, bacitracin, anisomycin and rifampicin, but not to ampicillin, chloramphenicol, erythromycin, neomycin or penicillin. The major polar lipids are $\mathrm{C}_{20} \mathrm{C}_{20}$ derivatives of phosphatidylglycerol, phosphatidylglycerol phosphate methyl ester, phosphatidylglycerol sulfate and sulfated mannosylglucosyl-glycerol diether. The DNA G $+\mathrm{C}$ content of the type strain is $65.7 \pm 0.5 \mathrm{~mol} \%\left(T_{\mathrm{m}}\right)$.

The type strain is strain $\mathrm{AJ} 201^{\mathrm{T}}\left(=\mathrm{CGMCC} 1.5343^{\mathrm{T}}=\mathrm{JCM}\right.$ $\left.13916^{\mathrm{T}}\right)$, isolated from a salt lake on the Qinghai-Tibet Plateau.

\section{Acknowledgements}

We thank Jean Euzéby for his help with the specific etymology and nomenclature. This work was supported by grants from the Major State Basic Research Development Program of China (973 Program) (grant no. 2004CB719604-3), the National Natural Science Foundation of China (grant no. 30670048) and the China Postdoctoral Science Foundation (grant no. 2005038636).

\section{References}

Castillo, A. M., Gutiérrez, M. C., Kamekura, M., Xue, Y., Ma, Y., Cowan, D. A., Jones, B. E., Grant, W. D. \& Ventosa, A. (2006). Halorubrum orientale sp. nov., a halophilic archaeon isolated from Lake Ejinor, Inner Mongolia, China. Int J Syst Evol Microbiol 56, 2559-2563.

Cui, H.-L., Tohty, D., Zhou, P.-J. \& Liu, S.-J. (2006). Halorubrum lipolyticum sp. nov. and Halorubrum aidingense sp. nov., isolated from two salt lakes in Xin-Jiang, China. Int J Syst Evol Microbiol 56, 1631-1634.

De Ley, J., Cattoir, H. \& Reynaerts, A. (1970). The quantitative measurement of DNA hybridization from renaturation rates. Eur $J$ Biochem 12, 133-142.

Fan, H., Xue, Y., Ma, Y., Ventosa, A. \& Grant, W. D. (2004). Halorubrum tibetense sp. nov., a novel haloalkaliphilic archaeon from Lake Zabuye in Tibet, China. Int J Syst Evol Microbiol 54, 1213-1216.

Feng, J., Zhou, P.-J. \& Liu, S.-J. (2004). Halorubrum xinjiangense sp. nov., a novel halophile isolated from saline lakes in China. Int J Syst Evol Microbiol 54, 1789-1791.

Feng, J., Zhou, P., Zhou, Y.-G., Liu, S.-J. \& Warren-Rhodes, K. (2005). Halorubrum alkaliphilum sp. nov., a novel haloalkaliphile isolated from a soda lake in Xin-Jiang, China. Int J Syst Evol Microbiol 55, 149-152.

Franzmann, P. D., Stackebrandt, E., Sanderson, K., Volkman, J. K., Cameron, D. E., Stevenson, P. L., McMeekin, T. A. \& Burton, H. R. (1988). Halobacterium lacusprofundi sp. nov., a halophilic bacterium isolated from Deep Lake, Antarctica. Syst Appl Microbiol 11, 20-27.

Grant, W. D. \& Larsen, H. (2001). Genus VII. Halorubrum. In Bergey's Manual of Systematic Bacteriology, 2nd edn, vol. 1, pp. 320-324. Edited by D. R. Boone, R. W. Castenholz \& G. M. Garrity. New York: Springer.

Huß, V. A. R., Festl, H. \& Schleifer, K. H. (1983). Studies on the spectrophotometric determination of DNA hybridization from renaturation rates. Syst Appl Microbiol 4, 184-192.

Kamekura, M. \& Dyall-Smith, M. L. (1995). Taxonomy of the family Halobacteriaceae and the description of two new genera, Halorubrobacterium and Natrialba. J Gen Appl Microbiol 41, 333-350.

Kamekura, M., Dyall-Smith, M. L., Upasani, V., Ventosa, A. \& Kates, M. (1997). Diversity of alkaliphilic halobacteria: proposals for transfer of Natronobacterium vacuolatum, Natronobacterium magadii, and Natronobacterium pharaonis to Halorubrum, Natrialba, and Natronomonas gen. nov., respectively, as Halorubrum vacuolatum comb. nov., Natrialba magadii comb. nov., and Natronomonas pharaonis comb. nov., respectively. Int J Syst Bacteriol 47, 853-857.

Kharroub, K., Quesada, T., Ferrer, R., Fuentes, S., Aguilera, M., Boulahrouf, A., Ramos-Cormenzana, A. \& Monteoliva-Sánchez, M. (2006). Halorubrum ezzemoulense sp. nov., a halophilic archaeon isolated from Ezzemoul sabkha, Algeria. Int J Syst Evol Microbiol 56, 1583-1588.

Kumar, S., Tamura, K. \& Nei, M. (2004). MEGA3: integrated software for molecular evolutionary genetics analysis and sequence alignment. Brief Bioinform 5, 150-163.

Lizama, C., Monteoliva-Sánchez, M., Suárez-García, A., RossellóMora, R., Aguilera, M., Campos, V. \& Ramos-Cormenzana, A. (2002). Halorubrum tebenquichense sp. nov., a novel halophilic archaeon isolated from the Atacama Saltern, Chile. Int J Syst Evol Microbiol 52, 149-155.

Marmur, J. \& Doty, P. (1962). Determination of the base composition of deoxyribonucleic acid from its thermal denaturation temperature. J Mol Biol 5, 109-118.

McGenity, T. J. \& Grant, W. D. (1995). Transfer of Halobacterium saccharovorum, Halobacterium sodomense, Halobacterium trapanicum 
NRC34021, and Halobacterium lacusprofundi to the genus Halorubrum gen. nov., as Halorubrum saccharovorum comb. nov., Halorubrum sodomense comb. nov., Halorubrum trapanicum comb. nov., and Halorubrum lacusprofundi comb. nov. Syst Appl Microbiol 18, 237-243.

Mwatha, W. E. \& Grant, W. D. (1993). Natronobacterium vacuolata sp. nov., a haloalkaliphilic archaeon isolated from Lake Magadi, Kenya. Int J Syst Bacteriol 43, 401-404.

Nuttall, S. D. \& Dyall-Smith, M. L. (1993). Ch2, a novel halophilic archaeon from an Australian solar saltern. Int J Syst Bacteriol 43, 729-734.

Oren, A. (1983). Halobacterium sodomense sp. nov., a Dead Sea halobacterium with an extremely high magnesium requirement. Int J Syst Bacteriol 33, 381-386.

Oren, A. \& Ventosa, A. (1996). A proposal for the transfer of Halorubrobacterium distributum and Halorubrobacterium coriense to the genus Halorubrum as Halorubrum distributum comb. nov. and Halorubrum coriense comb. nov., respectively. Int J Syst Bacteriol 46, 1180.

Oren, A., Ventosa, A. \& Grant, W. D. (1997). Proposal of minimal standards for the description of new taxa in the order Halobacteriales. Int J Syst Bacteriol 47, 233-238.

Sehgal, S. N. \& Gibbons, N. E. (1960). Effect of some metal ions on the growth of Halobacterium cutirubrum. Can J Microbiol 6, 165-169.
Thompson, J. D., Gibson, T. J., Plewniak, F., Jeanmougin, F. \& Higgins, D. G. (1997). The CLUSTAL_X windows interface: flexible strategies for multiple sequence alignment aided by quality analysis tools. Nucleic Acids Res 25, 4876-4882.

Tomlinson, G. A. \& Hochstein, L. I. (1976). Halobacterium sacharovorum sp. nov., a carbohydrate-metabolizing, extremely halophilic bacterium. Can J Microbiol 22, 587-591.

Trüper, H. G. (2003). Strain NCIMB 13488 may serve as the type strain of Halorubrum trapanicum. Opinion 74. Int J Syst Evol Microbiol 53, 933.

Ventosa, A., Gutiérrez, M. C., Kamekura, M., Zvyagintseva, I. S. \& Oren, A. (2004). Taxonomic study of Halorubrum distributum and proposal of Halorubrum terrestre sp. nov. Int J Syst Evol Microbiol 54, 389-392.

Xu, X.-W., Ren, P.-G., Liu, S.-J., Wu, M. \& Zhou, P.-J. (2005a). Natrinema altunense sp. nov., an extremely halophilic archaeon isolated from a salt lake in Altun Mountain in Xinjiang, China. Int J Syst Evol Microbiol 55, 1311-1314.

Xu, X.-W., Wu, M., Zhou, P.-J. \& Liu, S.-J. (2005b). Halobiforma lacisalsi sp. nov., isolated from a salt lake in China. Int J Syst Evol Microbiol 55, 1949-1952.

Zvyagintseva, I. S. \& Tarasov, A. L. (1987). Extreme halophilic bacteria from saline soils. Microbiology (English translation of Mikrobiologiia) 56, 664-669. 